\title{
LOW WAGES - COINCIDENCE OR A RESULT? EVIDENCE FROM POLAND
}

\author{
Maciej RYCZKOWSKI - Monika MAKSIM \\ (Received: 31 October 2016; revision received: 10 June 2017; \\ accepted: 10 November 2017)
}

The article evaluates the influence of a wide range of socio-demographic, job and company-related characteristics on the likelihood of low earnings by applying logistic regression on a broad range of Labour Force Survey data. We evidenced that the average impact of the company-related characteristics is three times stronger than the impact of personal characteristics. We also found that working full-time considerably decreases this risk of low wages, but company-related and personal characteristics (except for the kind of company's economic activity) have not provided a rent (benefit) from working full-time. The underlying conclusion is that reforms decreasing the size of the low-wage sector in the former transition countries should be focused on targeted employment programmes enhancing transitions to more profitable economic activities instead of possibly maintaining the unprofitable industries at all costs. Additionally, the reforms should be concentrated on introducing employment regulations to harmonise the rules of employment among all contract types, which would put the part-timers and the underemployed on a more equal footing with fulltime workers especially in terms of pension schemes and access to training.

Keywords: low wage earners, underemployment, primary labour market, working poor, wage inequality, Poland

JEL classification indices: J31, J71, J81

Maciej Ryczkowski, corresponding author. Associate Professor at the Department of Economics, Nicolaus Copernicus University, Torun and Labour Market Methodology Section, Statistical Office, Bydgoszcz, Poland. E-mail: m_ryczkowski@umk.pl

Monika Maksim, Associate Professor at the Department of Human Resource Management, Nicolaus Copernicus University, Torun, Poland. E-mail: mouso@umk.pl 


\section{INTRODUCTION}

While the majority of empirical research analyse the importance of the low or minimum wages (Bartkus 2016), the novelty of our study is explaining the probability to be paid low, following Belman et al. (2015) in this line of research. The issue is relevant (Schmitt 2012) because the expansion of the low-wage sector is a serious problem faced by many European Union (EU) countries. The growing number of individuals with low earnings in te EU and, particularly, in the transition countries is linked to increasing labour market segmentation, reflected in the development of temporary work, underemployment or involuntary selfemployment. These changes in the labour market are caused by the rapid rise in importance of information technologies, shifting labour market demand away from low-skilled towards high-skilled workers and global competition leading businesses to pursue urgent cost reductions (Frazer et al. 2011; European Commission 2011). There also might be a consequence of the national institutional context, for example, expansion of welfare-to-work policies (Spannagel 2013).

Low-wage employment causes negative consequences to individuals and to the whole economy (Pimenta et al. 2011). Low earnings increase the risk of inwork poverty, despite that only one quarter of the risk can be attributed to low wages (Strengemann-Kuhn 2003). Nevertheless, from an economic standpoint, employment should be the best prevention against poverty. Unfortunately, working full-time and on a permanent contract in Poland and in other post-communist countries, might not be a sufficient condition to avoid being poor (Bardone Guio 2005; European Commission 2011).

Additionally, low wages discourage individuals from taking up a job, especially if they are aware of state assistance, when the incentives to take up a job may be weakened by the discouraged worker effect (Gałecka-Burdziak - Pater 2016). Low wages may lead to the expansion of informal or parallel job markets. Moreover, Meuris - Leana (2015) provide evidence that low earnings contribute to profound psychological consequences that may spill over into organizational functioning. Finally, Cooper et al. (2014) prove that low income adversely affects individuals' good health. All this creates valid implications for the public policy, while improvements in the labour market in this respect may increase the quality of public life (Ręklewski - Ryczkowski 2016).

In the article we test two hypotheses. First, we expect that job, company and workplace-related characteristics are more important than personal characteristics when explaining the risk of low-wage employment (H1). The reasoning behind the hypothesis is that the labour market segmentation reflected in the development of unstable employment and low wages is perceived sometimes as a result of the job-related features but not of the employee-related ones (Kryńska 
1996). Certain job characteristics linked to the secondary labour market might be transferred to the employees, and thereby impeding the access to higher paid jobs (Sengenberger 1987). This hypothesis is also supported by Mosthaf et al. (2010), who argued that there do exist dead-end jobs and dead-end firms where workers face a very high risk of getting a low pay. The hypothesis seems to be, however, contradictory to the considerable importance of human capital (Ormiston 2016) and to the sizable impact of gender and/or age-discrimination (Cataldi et al. 2011; Mysíkova 2012).

In the second hypothesis we assume that full-time employment decreases the odds ratios (i.e. the risk) to be low-paid due to the socio-demographic, job and company-related characteristics (H2). In line with that, full-time employment should weaken the impact of factors that increase the probability to be low-paid and strengthen the influence of these, which reduce the risk of getting a low pay. The reasoning behind this hypothesis is that in accordance with the dual labour market theory (Doeringer - Piore 1971; Kryńska 1996) full-time employment is a feature of the primary labour market characterized by stable employment, relatively high wages, training opportunities and better prospects for career advancement. Access to jobs in the primary labour market is hampered by the strict criteria of employment and clearly defined career ladders. Following this theory, we believe that full-time employment constitutes a kind of protection for employees against overly low wages. Additionally, we aim to verify the impact of underemployment. A rising trend of involuntary part-time employment has been observed in most EU countries during the Great Recession and its aftermath (Veliziotis et al. 2015) making it an important problem of the modern labour market.

While the relevance of the different factors on wages has been verified in the previous studies, the research on the impact of the job and company-related characteristics, full-time employment and underemployment on the probability to be paid low is rather scarce and underestimated in debates concerning wages in Central and Eastern European (CEE) countries. Our article fills in this gap. Isolating factors responsible for low earnings may constitute a valuable contribution to communities and to policy makers responsible for formulating macroeconomic policies to fight this unfavourable phenomenon both at regional and national levels in the former transition countries with considerable share of low-wage earners and the economies similar to the Polish one. Therefore, the conclusions are not one-country oriented and the subsequent discussion concerns a wide range of countries.

In the neoclassical production function, output is a function of capital, labour and land, while marginal product of labour is equal to real wage. Although the research could be perceived as if the authors implicitly accepted the neoclassical production function (at least slightly), our goal was not to explain the wage setting behaviour but the probability to fall into low wages, while this might 
diverge from the concept of relative scarcity and marginal productivity of labour. It is because the reasons to be a low earner may stem, for instance, from the education completed, the individual choices concerning the work-life balance issues or mobility. The socio-demographic characteristics which we consider are at odds with neoclassical labour homogeneity as well as we do not account for any aggregated measure of capital. We examine the whole range of company-related characteristics instead.

The paper is organised as follows: Section 2 offers a review of the literature on the factors that may influence earning low. The data set and the methodology applied to verify their relative importance is presented in Section 3, while the empirical results of our econometric analysis are displayed and discussed in Section 4.

\section{LITERATURE REVIEW}

Previous studies suggest that typical reasons for low-wage work (a significant pathway leading into in-work poverty) are personal characteristics such as gender, age and educational attainment, etc. In particular, women are over-represented in low-wage jobs. To a given extent, it is argued to be a result of undervaluation of women's work, women's lower reservation wage and discriminatory workplace effects (Grimshaw 2011). Their upward wage mobility is also expected to be lower due to the interruptions in working life and the related loss of human capital, which was confirmed by Deding (2002) for Denmark and the USA, Viera (2005) for Portugal and Mosthaf et al. (2010) for Germany. Mason - Salverda (2010), in turn, found evidence for the significantly greater risk of a low pay among young workers and showed that the risk does not differ between male and female employees. Meanwhile, the mobility out of low-wage work is relatively high for young workers (Sloane - Theodossiou 2000; Westergaard-Nielsen 2008) because low-wage jobs may serve for them as stepping stones to better paid jobs (Mosthaf et al. 2010). Nevertheless, the importance of age factor in explaining the likelihood of low-wage work varies across the EU countries (European Commission 2011).

As for educational attainment, the higher the level of qualification obtained, the lower the incidence of low-wage work (European Commission Report 2011), which was also evidenced by Trejo (1997) for the Mexican Americans. Stewart Swaffield (1999) confirmed that education and professional experience reduce the risk of being trapped in a low-wage situation. Pavlopoulos et al. (2008) in a comparative analysis for the selected EU countries evidenced that greater upward wage mobility is more often associated with being highly qualified in France, Netherlands, Finland, the United Kingdom and Greece. In spite of the opposite 
result for Austria, Italy, Spain and Denmark, the low-skilled individuals are more often argued to face a greater risk of non-employment (Mosthaf 2014), involuntary part-time work (Kjelstad - Nymoen 2012), and then in consequence of being low earners.

It is evidenced that other characteristics such as, for instance, race, ethnicity or origin and migrant status might also be associated with low-wage employment (Grimshaw 2011). With regard to the United States, Pitts (2008) found evidence for a much higher incidence of low-wage work among black workers in full- and part-time jobs compared to whites. Being a migrant also played a significant role in explaining the higher risk of low-wage employment in the United Kingdom (Mason et al. 2008) and Denmark (Westergaard-Nielsen 2008). It seems, however, that these characteristics are of much less importance in the CEE countries, due to a considerable homogeneity of the labour force in terms of race, ethnicity and migrant status.

Except for individual characteristics, employees may face a greater risk of low-wage employment because of where their job is located (formal or informal sector, agriculture or other sections of economic activity, small or large, state or private-owned company). According to the study by Grimshaw (2011), low-wage work is usually concentrated in economic activities such as, for instance, retail and wholesale trade, hotels and restaurants, transport, social services, food processing and textiles. The size and sector affiliation of a company also significantly affects the individuals' probability of reaching a higher-paid job. This was confirmed by Cappellari (2002); Vieira (2005); Blázquez (2006); Grün et al. (2008); Schank et al. (2009); and Mosthaf et al. (2010). Larger companies compared to smaller ones more often have internal job markets with hierarchical wages and create better perspectives of career promotions offering their employees further training and other forms of human capital accumulation. In terms of upward wage mobility, Mosthaf et al. (2010) concluded that the best and usually most successful way to escape low-paid work is a change of occupation.

Finally, some researchers warn that low-wage work is a 'sticky' state and does not appear to be a self-correcting problem (Mishel - Eisenbrey 2015). In many EU countries, low-wage jobs do not seem to serve any longer as bridges between unemployment and stable and higher-paid employment. In a comparative study between Germany and Austria, Grün et al. (2008) found evidence for a great scale of low-wage persistence. This may lead to a threat of in-work poverty (Spannagel 2013), social cohesion (Schmitt 2012) and unemployment (Stewart 2007). In spite of the fact that some low-wage jobs can work as springboards to better-paid jobs (Knabe - Plum 2013), reducing the scale of the low-wage sector is beneficial for the economy and should remain one of the key objectives for national policies. 


\section{METHODOLOGY AND DATA}

Our data stem from the 2014 Polish Labour Force Survey (LFS). To meet the LFS definition of an employee, persons aged 15 and over were taken into account. The term 'employment' covers all persons engaged in productive activity that falls within the production boundary of the national accounts. Persons in employment are employees or the self-employed (European Union 2013 for more detail1).

We define low-wage thresholds at $2 / 3^{\text {rd }}$ of the median and first quartile of the gross monthly earnings (around 362 and 256 EUR net, respectively) in the main place of work. The threshold is proposed by the $\mathrm{OECD}^{2}$ to define a low pay and it is often used in the relevant literature (Maitre et al. 2012; Grimshaw 2011). Earnings include paid over-hours and bonuses recalculated to one month-value. For both thresholds separate logit models are estimated. Additionally, for the median threshold we estimate the logistic regression on the sample restricted to the fulltime employees. An analogous model for the $1^{\text {st }}$ quartile does not make sense as the wage would be below the minimum one. Full-time employees in our study are persons who usually work 40 hours a week in the main place of work and their work agreement has a written form.

Logistic regressions are models with the discreet endogenous variable. The response $Y$ of a subject may take two values denoted by $l$ and $O$ (if the employee earns low wage or less than the threshold then $Y=1$, and if the employee earns more than the threshold then $Y=0$ ). To explain the effects of the explanatory variables (represented by the vector: $x=\left(x_{1}, x_{2}, \ldots\right)$ on the binary response $Y$, the applied logit models take the form (Hosmer - Lameshow 1989) of:

$$
\operatorname{logit}\{\mathrm{P}(\mathrm{y}=1 \mid \mathrm{x})\}=\log \left(\frac{\mathrm{P}(\mathrm{y}=1 \mid \mathrm{x})}{1-\mathrm{P}(\mathrm{y}=1 \mid \mathrm{x})}\right)=\beta_{0}+x^{\prime} \beta,
$$

where $\beta_{0}$ is an intercept and $\beta$ is the slope parameter vector. The left side of the equation is the logarithm of the odds ratio, while the odds ratio is a relationship of the probability that $Y=1$ to the chance that $Y=0$. The unknown parameters in $\beta$ were estimated with a maximum likelihood method by finding values that maximize the likelihood function: $\prod_{i=1}^{N} p_{i}^{Y_{i}}\left(1-p_{i}\right)^{1-Y_{i}}$, where $i$ was the number of an individual with the probability $p$ to earn a low wage. We set the cut off value based on the Receiver Operating Characteristic (ROC) (King - Langche 2001) according to the formula given by DeLong et al. (1988). The threshold was deter- 
mined with the Youden index, the maximum vertical distance between the ROC curve and the 45-degree line (Kumar - Indrayan 2011).

The vector $x$ consisted of over one hundred binary variables representing socio-demographic characteristics, NUTS 2 regions and place of residence, company, contract and job-related characteristics, subjective individual's assessment on being in underemployment, on the main source of income and on the desire to work more for a higher wage, active search for another job, and upskilling through participation in courses, seminars or trainings within recent month. Statistically significant parameters, which entered the final models (for $\alpha \leq 0.1$ ) were presented in bold font (Tables 1-2 in Appendix).

\section{EMPIRICAL RESULTS}

The estimated regressions (Tables 1-2) fit significantly better than the reduced model with just the constant. The null hypothesis of the likelihood ratio tests was rejected. The odds ratio $(O R)$ value is greater than unity ${ }^{3}$, which confirms the goodness of the fit (Kufel 2007: 145). The values of McFadden $R$-squared and Adjusted $R$-squared are typical for regressions estimated on individual data and range between 0.3 and 0.35 , while higher values are common for aggregated data and time series (Wooldridge 2009). The percentages of correctly predicted cases range from 79 per cent (for both models with $2 / 3^{\text {rd }}$ median thresholds) to 94 per cent (for the model with $1^{\text {st }}$ quartile threshold). Sensitivity of the models with $2 / 3^{\text {rd }}$ median threshold amounts to 70 per cent, while for the $2 / 3^{\text {rd }}$ of the $1^{\text {st }}$ quartile it is 80 per cent. Specificity of all the models is similar at about $83-86$ per cent. In summary, the estimated regressions seem to have identified well the effects of the explanatory variables on the probability of earning low wages.

In all of the estimations, we evidenced that company-related characteristics (the company's size, sector of the ownership and economic activity) have a higher impact on the probability to earn low-wages than the personal characteristics (gender, age, the highest completed level and field of education). With regard to the whole sample model, the average impact of the company-related characteristics is over 3.5 times higher than the average impact of the personal char-

$3 \quad O R=\frac{n_{11} n_{00}}{n_{01} n_{10}}$, where $n_{11}$ is the number of cases when predicted and actual values $=1$ (i.e. true positives - number of persons found by the model to be paid low, which are actually paid low), $n_{00}$ is the number of cases when predicted and actual values $=0$ (i.e. true negatives), while $n_{01}$ is the number of cases when the actual $Y=0$ but the model estimated unity (i.e. false positives) and $n_{10}$ is the number of cases when the actual $Y=1$ but the model estimated zero (i.e. false negatives). 
acteristics. The standard deviations of the probabilities to earn low in case of both models are also substantially higher for the company-related characteristics than for the group of personal ones (2.1 times more in the whole sample model and 1.9 times more in the primary market model). This suggests that attaching importance by an individual to company-related characteristics should be done with a great deal of caution, because the choice gives a broader range of returns and penalties to the probability of earning low wages than the personal group of factors does. Thus, we accepted (H1) in an even stronger version, since we found that company-related characteristics are more important than all of the analysed groups of variables in influencing the probability to earn low wages. We, therefore, confirmed the existence of a firm size gap (Balkan -Tumen 2016), substantial differences in earnings across sectors (Magda et al. 2011) and the importance of the public and private ownership (Melly - Puhani 2013).

At first glance, the result may seem, however, to be at odds with studies which assign a leading role to education in shaping earnings and often demonstrate the positive relation between the highest completed level of education, its field, high school employment and future earnings (Trejo 1997). Possibly, our result could be explained by the evidence provided by Prime et al. (2016), who found that the presence of better educated people does not significantly increase the wage for any individual education cohort (but it results in a higher median wage in the whole community) and even the high school employment does not necessarily create occupation-specific human capital (Ormiston 2016). Therefore, while we do not deny the considerable and positive impact of education on the general wage level and following Ormiston (2016) to the role that education plays in building general human capital, our study indicates that the role of education is subordinate to the company-related features in influencing the risk of extremely low wages. We claim that sizable companies are usually associated with better chances of further training and other forms of human capital accumulation and thus with better perspectives for career promotions. Paying higher wages by big companies may also be treated by them as an effective labour turnover stabilizing tool (Duhautois et al. 2016).

With reference to (H2), full-time employment is a feature of the primary labour market and we expected it to lower the probability of being low-paid separately for each of the personal and company-related characteristics. Nevertheless, the estimated probabilities to be paid low for the whole sample (Table 1) and for the employed only full-time (Table 2) are very similar in case of the majority of the coefficients. More than 75 per cent of the estimated coefficients turned out to have the same sign and to be significant in both regressions. If we exclude the coefficients that make the greatest discrepancy between the two models, namely, the coefficients associated with economic activity sections, being over 70 and having 
job experience of less than one year, the standard deviation of the differences between the models' estimated probabilities (corresponding to analogous coefficients) amounts to less than 5 p.p. Moreover, the slight improvement stemming from full employment concerns merely $50 \%$ of the estimated variables. Only in case of economic activity sections, the probabilities to be paid low in the primary, more-secure-job market are significantly lower, roughly by two to six times. This may suggest that employees with less-secure jobs are simply paid less (Pinheiro - Visschers 2015) but the difference seems to be driven by company's economic activity, while other company-related or personal characteristics do not provide a rent (benefit) from working full-time. In consequence, we rejected (H2).

Despite the rejection of $(\mathrm{H} 2)$, it is argued in the literature of this subject that contingent jobs (part-time, dispatch or temporary workers) are usually associated with the secondary market and may have a lasting effect on the welfare of the individual (Esteban-Pretel et al. 2011). Indeed, we found that working part-time significantly increased the likelihood of being in a low-wage situation (compare: Paul 2016). As noticed by Matteazzi et al. (2014), this effect may be particularly strong in Poland and in the United Kingdom, where part-timers are mostly concentrated in low-skilled occupations. Our results indicate that the willingness to work longer in return for a higher pay and underemployment (that is a willingness to work longer while working part-time) is strongly correlated. In all of the models we always found one of the two variables to be significant. In the models with the $2 / 3^{\text {rd }}$ of the median threshold, the risk was increased by over 45 per cent. In the model with the $2 / 3^{\text {rd }}$ of the first quartile threshold (which we do not present to save space), the underemployment translated into an upsurge of the mentioned risk by over 4,000 per cent. This indicates that below a certain wage, the desire to escape from the unfavourable situation rises markedly. The results contribute to filling the gap in the literature which pays relatively little attention to the problem of underemployment. Meanwhile, the underemployed should be of special concern for policymakers, since according to our study the group is highly endangered by the increased probability of low wages. Otherwise, underemployment may lead to persistent poverty (Caceres - Caceres 2015) mostly for the secondary labour market that typically involves low-skill, low-pay work with a high turnover (Kjelstad - Nymoen 2012).

In our analysis we have also found several other thought-provoking results. While most studies confirm the existence of the gender pay gap in the CEE countries (Goraus -Tyrowicz 2014; Śliwicki - Ryczkowski 2014; Perugini - Selezneva 2015), our results deliver novel evidence that women's inferior situation may also exist in terms of the probability to fall into the group of low earners. Indeed, we found that men's probability to earn low was almost 73 per cent smaller. This may suggest potential discrimination, although the difference might be the result of 
females' lower average number of overtime hours, work-life balance problems, lesser interest in taking top managerial positions (Oczki 2014) or less aggressive wage negotiations (Leibbrandt - List 2015). As for the marital status, we found that especially high risk of low earnings concerns single individuals. Thus, we confirmed the results of Kim (2000) concerning the unfavourable impact of being single, although his sample consisted only of women.

Having family duties considerably increased the probability of earning low wages as well. Thus, we contributed to the lesser recognized impact of 'household activities' on wages in the literature. In this respect, our results are close to Bryan - Sevilla-Sanz (2010), however, they concluded that this effect was present for both married and single men and women working full-time, while housework penalty concerned only single women among women working part-time.

Youth's probability of earning low is 21 and 13 per cent lower for the 15-24 and 25-30 age groups, respectively, than that of the prime-wage workers in the middle-age. Meanwhile, several studies for different EU countries indicated a higher risk for young people to be low earners (Westergaard-Nielsen 2008; Mosthaf et al. 2010). We argue that while young age is rewarded, young persons have penalties for usually shorter job experience. Indeed, our estimates indicate that job experience significantly reduced the odds of being low-paid, which is consistent with human capital theory (Becker 1964; Mincer 1974). This conclusion, we believe, may have practical applications as according to our results the regional or national support should be rather targeted not only to the young, as it is explicitly or implicitly argued in many studies (Kim 2000; Grimshaw 2014), but rather to those with no or only shorter job experience. Considering age, the probability to earn low wages starts increasing with the age of 50. This may indicate an unfavourable situation for people over 50 in the labour market and might be interpreted as contradictory to the results of Deelen - Euwals (2014), who provided evidence of a wage cushion in the private sector that allows wages to continue to increase with age. We believe that our results are complementary by indicating that the situation of people over certain older age becomes diversified and the group should not be treated as homogeneous. While some older people face greater risks of earning low wages, the group of presumably the most educated, valuable employees makes use of their job-experience-rent.

Surprisingly, the fact of being employed in education, professional, scientific and technical activities, and also in real estate creates the highest risk of a low-wage situation. Meanwhile other authors point rather to retail and wholesale trade, hotels and restaurants, transport, home-care as industries with fastest growing low-wage sector (Grimshaw 2011; Howes 2015). This could be possibly due to the fact that we estimated the basic 21 NACE Rev. 2 sections, which may lead to overly general treatment of some sub-sections. Nevertheless, the 
outcome for education in terms of low wages is disappointing. It may partly be associated with an unfavourable demographic situation which causes a decrease in demand for educational services and thus reduces upward pressure on wages. High incidence of low-wage work in such sectors, such as education and scientific activity seems to be a serious barrier to innovate and build a knowledgebased economy in Poland.

Our results confirmed that the higher the university degree, the lower is the risk of earning low. At the same time low-skilled individuals have an increased likelihood of being low-wage earners. Possible explanations include different mobility to better jobs among people with particular education attainments (Knabe - Plum 2013, compare with: Pavlopoulos et al. 2008) or due to globalisation and offshoring (Giesicke - Verwiebe 2009; Wolszczak-Derlacz - Parteka 2016). We also found that individuals who live in less economically developed regions are more likely to be in a low-wage situation, which may be explained by the geography of access to markets (Cieślik - Rokicki 2016).

\section{CONCLUSIONS}

We found that the low-wage situation could be interpreted largely as a result of socio-demographic, job and company-related characteristics. The novelty of the article is explaining the probability to be paid low, as opposed to the majority of the subject literature which often deals with the levels of low or minimum wages. The issue raised in the article is relevant as the expanding low-wage sector translates into severe consequences for the economy and individuals. The study complemented the scarce evidence on the importance of company-related attributes in comparison to other factors. We found that the average impact of companyrelated characteristics was three times stronger than the impact of personal ones. We accepted, thus, the first hypothesis. In turn, although the employed part-time and underemployed exhibited a greater risk to be paid little, the personal and company-related traits (except for the kind of company's economic activity) have not provided a rent (benefit) from working full-time. The second hypothesis was, therefore, rejected. We evidenced, thus, the existence of a firm size gap and substantial differentiation of the low-wage risk across the economic activity sections. Our results suggest that decreasing the size of the low-wage sector should be carried out by policies focused not only on raising the general human capital of an individual, but also on enhancing transitions of employees to companies conducting more profitable economic activities, instead of possibly maintaining the employees in unprofitable industries at all costs. This could be dealt with by enacting special employment programs targeted toward hard-hit communities 
and aimed at increasing their incomes from work (Mishel - Eisenbrey 2015). The favourable results for the information and communication suggest that the priority should be given to the high-tech industries and branches. Meanwhile, for Poland and for some other post transition countries there still exists an urgency to reform the uncompetitive industries, including the coal industry. Following Richardson (1999: 11), we believe that the power of government should be used to prevent unfair and desperate exchanges 'of work for pay'. In case of part-timers, underemployed and temporary workers, we think that introducing labour market reforms that seek to improve labour standards and aim to put precarious workers on a more equal footing with permanent, full-time workers, especially in terms of pension schemes and access to training, could bring substantial benefits (Dobbs et al. 2016). These kinds of reforms have been already introduced in Denmark, Germany and the Netherlands. Meanwhile, the inferior position of women in terms of higher risk to earn extremely low, could be improved. We believe that the development of institutional care, especially caring and housework services would enable women to work longer (which would decrease the unfavourable impact of underemployment, part-time employment or 'household activities') and to take higher and better-paid job positions. In turn, the regional or national support, according to our results, should be rather targeted not only to the young as it is explicitly or implicitly argued in many studies but rather to those with no or only shorter job experience. The limits of the research are associated with the lack of taking into account non-cognitive (Lundborg et al. 2014) and some cognitive skills due to the limitations of the LFS database. Additionally, we have not analysed whether low-wage employment is transitory or persistent. We leave it for future research.

\section{REFERENCES}

Balkan, B. - Tumen, S. (2016): Firm-Size Wage Gaps along the Formal-Informal Divide: Theory and Evidence. Industrial Relations, 55(2): 235-266, doi: 10.1111/irel.12135.

Bardone, L. - Guio, A. C. (2005): In-Work-Poverty. New Commonly Agreed Indicators at the EU Level. Statistics in Focus - Population and Social Conditions, 5: 1-11.

Bartkus, A. (2016): The Minimum Wage and the Lithuanian Labour Market. Economics of Transition, 25(1): 47-55, doi: 10.1111/ecot.12111.

Becker, G. (1964): Human Capital: A Theoretical and Empirical Analysis, with Special Reference to Education. New York: National Bureau of Economic Research.

Belman, D. - Wolfson, P. - Nawakitphaitoon, K. (2015): Who is Affected by the Minimum Wage? Industrial Relations, 54(4): 582-621, doi: 10.1111/irel.12107.

Blázquez, M. (2006): The Probability of Leaving a Low-Paid Job in Spain: The Importance of Switching into Permanent Employment. Revista de Economia Laboral, 3(1): 58-86, doi: 10.21114/rel.2006.01.04. 
Bryan, M. L. - Sevilla-Sanz, A. (2010): Does Housework Lower Wages? Evidence for Britain. Oxford Economic Papers, 63(1): 187-210, doi: 10.1093/oep/gpq011.

Caceres, L. R. - Caceres, S. A. (2015): Underemployment in Latin America. The Journal of Developing Areas, 49(3): 293-322, doi: 10.1353/jda.2015.0150.

Cappellari, L. (2002): Do the "Working Poor" Stay Poor? An Analysis of Low Pay Transitions in Italy. Oxford Bulletin of Economics and Statistics, 64(2): 87-110, doi: 10.1111/1468-0084.00014.

Cataldi, A. - Kampelmann, S. - Rycx, F. (2011): Productivity-Wage Gaps among Age Groups: Does the ICT Environment Matter? De Economist, 159(2): 193-221, doi: 10.1007/s10645-011 -9162-9.

Cieślik, A. - Rokicki, B. (2016): Individual Wages and Regional Market Potential. Economics of Transition, 24(4): 661-682, doi: 10.1111/ecot.12102.

Cooper, D. - Mccausland, W. - Theodossiou, I. (2014): Is Unemployment and Low Income Harmful to Health? Evidence from Britain. Review of Social Economy, 73(1): 34-60, doi: 10.1080/00346764.2014.986969.

Deding, M. C. (2002): Low Wage Mobility in Denmark, Germany and the United States. Welfare Distribution Working Paper, No. 33, The Danish National Institute of Social Research, http:// pure.sfi.dk/ws/files/291978/wp332002.pdf.

Deelen, A. - Euwals, R. (2014): Do Wages Continue Increasing at Older Ages? Evidence on the Wage Cushion in the Netherlands. De Economist, 162(4): 433-460, doi: 10.1007/s10645-0149237-5.

DeLong, E. R. - DeLong, D. M. - Clarke-Pearson, D. L. (1988): Comparing the Areas under Two or More Correlated Receiver Operating Characteristic Curves: A Nonparametric Approach. Biometrics, 44(3): 837-845. doi: 10.2307/2531595.

Dobbs, R. - Madgavkar, A. - Manyika, J. - Woetzel, J. - Bughin, J. - Labaye, E. - Kashyap, P. (2016): Poorer than Their Parents? Flat or Falling Incomes in Advanced Economies. Report. McKinsey Global Institute.

Doeringer, P. B. - Piore, M. J. (1971): Internal Labor Markets and Manpower Analysis. Mass.: Heath and Lexington Books.

Duhautois, R. - Gilles, F. - Petit, H. (2016): Decomposing the Relationship between Wage and Churning. International Journal of Manpower, 37(4): 660-683, doi: 10.1108/ijm-04-20140100 .

Esteban-Pretel, J. - Nakajima, R. - Tanaka, R. (2011): Are Contingent Jobs Dead Ends or Stepping Stones to Regular Jobs? Evidence from a Structural Estimation. Labour Economics, 18(4): 513-526, doi: 10.1016/j.labeco.2010.12.010.

European Commission (ed.) (2011): Is Working Enough to Avoid Poverty? In-Work Poverty Mechanisms and Policies in the EU. In: Employment and Social Developments in Europe.

European Union (2013): European System of Accounts ESA 2010. Luxembourg, ISBN 978-92-7931242-7.

Frazer, N. - Gutiérrez, R. - Peña-Casas, R. (2011): Introduction. In: Frazer, N. - Gutiérrez, R. Peña-Casas, R. (eds): Working Poverty in Europe. A Comparative Approach. Basingstoke: Palgrave Macmillan, pp. 1-12, doi: 10.1057/9780230307599.

Gałecka-Burdziak, E. - Pater, R. (2016): Discouraged or Added Worker Effect: Which One Prevails in the Polish Labour Market? Acta Oeconomica, 66(3): 489-505, doi: 10.1556/032.2016.66.3.6.

Giesecke, J. - Verwiebe, R. (2009): Wachsende Lohnungleichheit in Deutschland. Qualifikationsund Klessenspezifische Determination der Entlohnung zwischen 1998 und 2006. Berliner Journal für Soziologie, 19(4): 531-555, doi: 10.1007/s11609-009-0108-x. 
Goraus, K. - Tyrowicz, J. (2014): Gender Wage Gap in Poland - Can it be Explained by Differences in Observable Characteristics? Ekonomia, 36: 125-148.

Grimshaw, D. (2011): What Do We Know about Low-Wage Workers? Analysing the Definitions, Patterns, Causes and Consequences in International Perspective. ILO Working Papers, No. 464858, Conditions of Work and Employment series, http://www.ilo.org/public/libdoc/ ilo/2011/111B09 120 engl.pdf

Grimshaw, D. (2014): At Work but Earning Less: Trends in Decent Pay and Minimum Wages for Young People. ILO Working Paper, No. 486283, http://www.ilo.org/wcmsp5/groups/public/--ed_emp/documents/publication/wcms_340067.pdf.

Grün, C. - Lutz, H. - Mahringer, H. - Rhein, T. (2008): Being Low Paid: Springboard or Dead End? Evidence from Administrative Data in Germany and Austria. Paper presented for the $3^{\text {rd }}$ User Conference on the Analysis of BA and IAB Data in Nuremberg, 5-6 September 2008, http://doku.iab.de/fdz/events/2008/Rhein.pdf.

Hosmer, D. W. - Lemeshow, S. (1989): Applied Logistic Regression. New York: Wiley\&Sons, doi: 10.1002/sim.4780100718.

Howes, C. (2015): Home Care: The Fastest Growing Low-Wage Industry. New Labor Forum, 24(2): 98-105, doi: 10.1177/1095796015579692.

Kim, M. (2000): Women Paid Low Wages: Who They Are and Where They Work. Monthly Labor Review, September: 26-30.

King, G. - Langche, Z. (2001): Logistic Regression in Rare Events Data. Political Analysis, 9(2): 137-163, doi: 10.1093/oxfordjournals.pan.a004868.

Kjelstad, R. - Nymoen, E. H. (2012): Part-Time Work and Gender: Worker versus Job Explanations. International Labour Review, 151(1-2): 85-107, doi: 10.1111/j.1564-913x.2012.00136.x.

Knabe, A. - Plum, A. (2013): Low-Wage Jobs - Springboard to High-paid Ones? Labour, 27(3): 310-330, doi: 10.1111/labr.12015.

Kryńska, E. (1996): Segmentacja rynku pracy. Podstawy teoretyczne i analiza statystyczna (Labour Market Segmentation. Theoretical Basics and the Statistical Analysis). Łódź: Uniwersytet Łódzki.

Kufel, T. (2007): Ekonometria. Rozwiąywanie problemów z programem Gretl (Econometrics. Solving Problems with the Gretl Software). Warszawa: PWN.

Kumar, R. - Indrayan, A. (2011): Receiver Operating Characteristic (ROC) Curve for Medical Researchers. Indian Pediatrics, 48(4): 277-287, doi: 10.1007/s13312-011-0055-4.

Leibbrandt, A. - List, J. A. (2015): Do Women Avoid Salary Negotiations? Evidence from a Large Scale Natural Field Experiment. Management Science, 61(9): 2016-2024, doi: 10.1287/ mnsc.2014.1994.

Lundborg, P. - Nystedt, P. - Rooth, D. O. (2014): Height and Earnings: The Role of Cognitive and Noncognitive Skills. Journal of Human Resources, 49(1): 141-166, doi: 10.1353/ jhr.2014.0006

Magda, I. - Rycx, F. - Tojerow, I. - Valsamis, D. (2011): Wage Differentials across Sectors in Europe. Economics of Transition, 19(4): 749-769, doi: 10.1111/j.1468-0351.2011.00417.x.

Maitre, B. - Nolan, B. - Whelan, C. T. (2012): Low Pay, In-Work Poverty and Economic Vulnerability: A Comparative Analysis Using Eu-Silc. Manchester School (14636786), 80(1): 99-116. doi: 10.1111/j.1467-9957.2011.02230.x.

Mason, G. - Mayhew, K. - Osborne, M. - Stevens, P. (2008): Low Pay, Labour Market Institutions and Job Quality in the United Kingdom. In: Lloyd, C. - Mason, G. - Mayhew, K. (eds): LowWage Work in the United Kingdom. New York: Russel Sage Foundation, pp. 41-95. 
Mason, G. - Salverda, W. (2010): Low Pay, Working Conditions, and Living Standards. In: Gautié, J. - Schmitt, J. (eds): Low Wage Work in the Wealthy World. New York: Russel Sage Foundation, pp. 35-90.

Matteazzi, E. - Pailhé, A. - Solaz, A. (2014): Part-Time Wage Penalties for Women in Prome Age: A Matter of Selection or Segregation? Evidence from European Countries. Industrial \& Labor Relations Review, 67(3): 955-985, doi: 10.1177/0019793914537457.

Melly, B. - Puhani, P. A. (2013): Do Public Ownership and Lack of Competition Matter For Wages and Employment? Evidence from Personnel Records of a Privatized Firm. Journal of the European Economic Association, 11(4): 918-944, doi: 10.1111/jeea.12024.

Meuris, J. - Leana, C. R. (2015): The High Cost of Low Wages: Economic Scarcity Effects in Organizations. Research in Organizational Behavior, 35: 143-158, doi: 10.1016/J.Riob.2015.07.001.

Mincer, J. (1974): Schooling, Experience and Earning. New York: National Bureau of Economic Research.

Mishel, L. - Eisenbrey, R. (2015): How to Raise Wages? Policies that Work and Policies that don't. Economic Policy Inistitute Briefing Paper, No. 39: 1-17.

Mosthaf, A. (2014): Do Scarring Effects of Low-Wage Employment and non-Employment Differ between Levels of Qualification? Scottish Journal of Political Economy, 61(2): 154-177, doi: 10.1111/Sjpe.12039.

Mosthaf, A. - Schnabel, C. - Stephani, J. (2010): Low-Wage Careers: Are There Dead-End Firms and Dead-End Jobs? Zeitschrift für Arbeitsmarktforschung, 43(3): 231-249, doi: 10.1007/ S12651-010-0036-4.

Mysíková, M. (2012): Gender Wage Gap in the Czech Republic and Central European Countries. Prague Economic Papers, 21(3): 328-346, doi: 10.18267/J.Pep.427.

Oczki, J. (2015): Nierówności ze Względu na Płeć na Rynku Pracy w Polsce (Labour Market Gender Inequalities in Poland). Polityka Spoteczna, 7: 26-29.

Ormiston, R. (2016): Does High School Employment Develop Marketable Skills? Journal of Labor Research, 37(1): 53-68, doi: 10.1007/S12122-015-9219-7.

Paul, M. (2016): Is There a Causal Effect of Working Part-Time on Current and Future Wages? Scandinavian Journal of Economics, 118(3): 494-523, doi: 10.1111/Sjoe.12157.

Pavlopoulos, D. - Muffels, R. - Vermunt, J. K. (2008): Wage Mobility in Europe. A Comparative Analysis Using Restricted Multinomial Logit Regression. Quality \& Quantity, 44(1): 115-129, doi: 10.1007/S11135-008-9185-8.

Perugini, C. - Selezneva, E. (2015): Labour Market Institutions, Crisis and Gender Earnings Gap in Eastern Europe. Economics of Transition, 23(3): 517-564, doi: 10.1111/Ecot.12072.

Pimenta, A. - Silva, F. - Vieira, J. (2011): Duration of Low Wage Employment: A Study Based on a Survival Model. IZA Disussion Paper, No. 5972, Bonn, http://Ftp.Iza.Org/Dp5972.Pdf.

Pinheiro, R. - Visschers, L. (2015): Unemployment Risk and Wage Differentials. Journal of Economic Theory, 157: 397-424, doi: 10.1016/J.Jet2015.01.019.

Pitts, S. (2008): Job Quality and Black Workers. Berkeley: Centre for Labor Research and Education.

Prime, P. B. - Grimes, D. - Walker, M. B. (2016): Exploring Wage Determination by Education Level: A U.S. Metropolitan Statistical Area Analysis from 2005 to 2012. Economic Development Quarterly, 30(3): 191-202, doi: 10.1177/0891242416628995.

Ręklewski, M. - Ryczkowski, M. (2016): The Polish Regional Labour Market Welfare Indicator and Its Links to Other Well-Being Measures. Comparative Economic Research, 19(3): 113-132, doi: 10.1515/Cer-2016-0023.

Richardson, S. (Ed.) (1999): Reshaping the Labour Market, Regulation, Efficiency and Equality in Australia. Cambridge: Cambridge University Press, ISBN: 0521652812. 
Schank, T. - Schnabel, C. - Stephani, J. (2009): Geringverdiener: Wem und Wie Gelingt der Aufstieg? Jahrbücher für Nationalökonomie und Statistik, 229(5): 584-614, doi: 10.1515/Jbnst2009-0505.

Schmitt, J. (2012): Low-Wage Lessons. CEPR Reports and Issue Briefs, No. 2012-03, http://Cepr. Net/Documents/Publications/Low-Wage-2012-01.Pdf.

Sengenberger, W. (1987): Struktur und Funktionsweise von Arbeitsmärkten. Die Bundesrepublik Deutschland im Internationalen Vergleich. Frankfurt-New York: Campus Verlag.

Śliwicki, D. - Ryczkowski, M. (2014): Gender Pay Gap in the Micro Level - Case of Poland. Quantitative Methods in Economics, 15(1): 159-173.

Sloane, P. - Theodossiou, I. (2000): Earnings Mobility of the Low Paid. In: Gregory, M. - Salverda, W. - Bazen, S. (eds): Labour Market Inequalities: Problems and Policies of Low Wage Employment in International Perspective. Oxford: Oxford University Press, Ch. 4.

Spannagel, D. (2013): In-Work Poverty in Europe. Extent, Structure and Causal Mechanisms. COPE Publications and Reports, http://Cope-Research.Eu/Wp-Content/Uploads/2013/03/InWork_Poverty_In_Europe.Pdf

Stewart, M. B. (2007): The Interrelated Dynamics of Unemployment and Low-Wage Employment. Journal of Applied Econometrics, 22(3): 511-531, doi: 10.1002/Jae.922.

Stewart, M. B. - Swaffield, J. K. (1999): Low Pay Dynamics and Transition Probabilities. Economica, 66(261): 23-42.

Strengmann-Kuhn, W. (2003): Armut trotz Erwerbstätigkeit. Analysen und Sozialpolitische Konsequenzen. Frakfurt Am Main: Campus.

Trejo, S. J. (1997): Why Do Mexican Americans Earn Low Wages? Journal of Political Economy, 105(6): 1235-1268, doi: 10.1086/516391.

Veliziotis, M. - Matsaganis, M. - Karakitsios, A. (2015): Involuntary Part-Time Employment: Perspectives from Two European Labour Markets. Improve Working Paper, No. 15/02, http://www. Centrumvoorsociaalbeleid.Be/Improve/Working\%20Papers/Improve\%20WP\%201502_1.Pdf.

Vieira, J. (2005): Low Wage Mobility in the Portuguese Labour Market. Portuguese Economic Journal, 4(1): 1-14, doi: 10.1007/S10258-005-0038-2.

Westergard-Nielsen, N. (2008): Statistical Analysis and History of Low-Wage Work in Denmark. In: Westergaard-Nielsen, N. (ed.): Low-Wage Work in Denmark. New York: Russel Sage Foundation, pp. 32-103.

Wolszczak-Derlacz, J. - Parteka, A. (2016): The Effects of Off-shoring to Low-Wage Countries on Domestic Wages - A Worldwide Industrial Analysis. GUT FME Working Paper Series A, No. 36, Gdansk University of Technology, ftp://ftp.zie.pg.gda.pl/RePEc/gdk/wpaper/WP GUTFME_A_36_WolszczakDerlacz_Parteka.pdf.

Wooldridge, J. M. (2009): Introductory Econometrics: A Modern Approach. $4^{\text {th }}$ ed., Mason: SouthWestern. 


\section{APPENDIX}

Table 1. Parameter estimates of being a low-wage earner ( $2 / 3$ of the national median), all employees, Poland, 2014

\begin{tabular}{|c|c|c|c|c|c|c|}
\hline Explanatory Variables & $\begin{array}{l}\text { Coef- } \\
\text { ficient }\end{array}$ & $\begin{array}{l}\text { Std. } \\
\text { error }\end{array}$ & $Z$ & Slope & $\begin{array}{l}\text { Odds } \\
\text { ratio }\end{array}$ & $\begin{array}{c}\Delta \text { low } \\
\text { wage } \\
\text { risk }(\%)\end{array}$ \\
\hline Constant & 2.522 & 0.170 & 14.87 & & & \\
\hline Male & -1.304 & 0.042 & -31.41 & -0.29 & 0.27 & -72.86 \\
\hline Single & 0.195 & 0.047 & 4.14 & 0.05 & 1.22 & 21.51 \\
\hline Widowed & 0.093 & 0.108 & 0.85 & 0.02 & 1.1 & 0.1 \\
\hline Divorced & 0.103 & 0.074 & 1.4 & 0.02 & 1.11 & 0.11 \\
\hline Age 15-24 & -0.239 & 0.094 & -2.55 & -0.05 & 0.79 & -21.26 \\
\hline Age 25-30 & -0.136 & 0.063 & -2.14 & -0.03 & 0.87 & -12.72 \\
\hline Age 50-59 & 0.396 & 0.060 & 6.61 & 0.09 & 1.49 & 48.54 \\
\hline Age 60-69 & 0.665 & 0.113 & 5.91 & 0.16 & 1.95 & 94.52 \\
\hline Age 70 plus & 1.152 & 0.406 & 2.84 & 0.28 & 3.16 & 216.41 \\
\hline Retirement & 1.290 & 0.151 & 8.52 & 0.31 & 3.63 & 263.12 \\
\hline Disability pension & 1.225 & 0.222 & 5.53 & 0.30 & 3.40 & 240.46 \\
\hline Being a kept person & 0.673 & 0.364 & 1.85 & 0.16 & 1.96 & 96.04 \\
\hline Having a farm & 0.279 & 0.078 & 3.60 & 0.07 & 1.32 & 32.22 \\
\hline Family responsibilities & 0.663 & 0.200 & 3.32 & 0.16 & 1.94 & 94.10 \\
\hline Student & 0.615 & 0.504 & 1.22 & 0.15 & 1.85 & 0.85 \\
\hline Disabled & 0.655 & 0.545 & 1.2 & 0.16 & 1.92 & 0.92 \\
\hline Ph.D. degree and higher & -1.578 & 0.449 & -3.51 & -0.25 & 0.21 & -79.36 \\
\hline Master degree & -0.883 & 0.068 & -12.92 & -0.18 & 0.41 & -58.66 \\
\hline Bachelor & -0.244 & 0.079 & -3.10 & -0.05 & 0.78 & -21.63 \\
\hline $\begin{array}{l}\text { Vocational education, no } \\
\text { examination }\end{array}$ & 0.261 & 0.082 & 3.18 & 0.06 & 1.30 & 29.82 \\
\hline Secondary school* & -0.797 & 0.092 & -8.69 & -0.16 & 0.45 & -54.91 \\
\hline $\begin{array}{l}\text { Secondary school, no } \\
\text { examination }\end{array}$ & -0.547 & 0.131 & -4.17 & -0.11 & 0.58 & -42.14 \\
\hline Basic vocational education & 0.520 & 0.049 & 10.71 & 0.12 & 1.68 & 68.21 \\
\hline Gymnasium & -0.706 & 0.181 & -3.91 & -0.14 & 0.49 & -50.66 \\
\hline Primary & -1.46 & 1.603 & -0.91 & -0.25 & 0.23 & -0.77 \\
\hline Post-secondary school & -0.038 & 0.095 & -0.4 & -0.01 & 0.96 & -0.04 \\
\hline College & 0.443 & 0.75 & 0.59 & 0.11 & 1.56 & 0.56 \\
\hline No overall job tenure & 1.876 & 0.155 & 12.11 & 0.43 & 6.53 & 552.75 \\
\hline $\begin{array}{l}\text { Overall job tenure less than } \\
1 \text { year }\end{array}$ & 1.414 & 0.118 & 12.00 & 0.34 & 4.11 & 311.16 \\
\hline $\begin{array}{l}\text { Overall job tenure more than } \\
1 \text { year and less than } 5 \text { years }\end{array}$ & 0.608 & 0.069 & 8.86 & 0.15 & 1.84 & 83.59 \\
\hline $\begin{array}{l}\text { Overall job tenure more than } \\
10 \text { years and less than } 20 \text { years }\end{array}$ & -0.414 & 0.058 & -7.11 & -0.09 & 0.66 & -33.87 \\
\hline
\end{tabular}


Table 1. continued

\begin{tabular}{|c|c|c|c|c|c|c|}
\hline Explanatory Variables & $\begin{array}{l}\text { Coef- } \\
\text { ficient }\end{array}$ & $\begin{array}{l}\text { Std. } \\
\text { error }\end{array}$ & $Z$ & Slope & $\begin{array}{l}\text { Odds } \\
\text { ratio }\end{array}$ & $\begin{array}{c}\Delta \text { low } \\
\text { wage } \\
\text { risk }(\%) \\
\end{array}$ \\
\hline $\begin{array}{l}\text { Overall job tenure more than } \\
20 \text { years and less than } 30 \text { years }\end{array}$ & -0.640 & 0.065 & -9.89 & -0.14 & 0.53 & -47.28 \\
\hline $\begin{array}{l}\text { Overall job tenure more than } \\
30 \text { years and less than } 40 \text { years }\end{array}$ & -1.019 & 0.084 & -12.11 & -0.20 & 0.36 & -63.89 \\
\hline $\begin{array}{l}\text { Overall job tenure more than } \\
40 \text { years }\end{array}$ & -1.025 & 0.131 & -7.81 & -0.19 & 0.36 & -64.12 \\
\hline Upskilling & -0.511 & 0.137 & -3.73 & -0.11 & 0.60 & -40.01 \\
\hline PL 51 dolnośląskie & -0.247 & 0.079 & -3.11 & -0.05 & 0.78 & -21.92 \\
\hline PL 61 kujawsko-pomorskie & 0.418 & 0.074 & 5.64 & 0.10 & 1.52 & 51.87 \\
\hline PL 31 lubelskie & 0.430 & 0.064 & 6.71 & 0.10 & 1.54 & 53.71 \\
\hline PL 21 małopolskie & -0.207 & 0.075 & -2.77 & -0.05 & 0.81 & -18.67 \\
\hline PL 12 mazowieckie & -0.407 & 0.060 & -6.83 & -0.09 & 0.67 & -33.45 \\
\hline PL 32 podkarpackie & 0.750 & 0.073 & 10.24 & 0.18 & 2.12 & 111.71 \\
\hline PL 34 podlaskie & 0.419 & 0.067 & 6.23 & 0.10 & 1.52 & 52.00 \\
\hline PL 33 świętokrzyskie & 0.436 & 0.073 & 5.97 & 0.10 & 1.55 & 54.62 \\
\hline PL 62 warmińsko-mazurskie & 0.274 & 0.070 & 3.93 & 0.06 & 1.32 & 31.51 \\
\hline PL 41 wielkopolskie & 0.155 & 0.069 & 2.25 & 0.04 & 1.17 & 16.74 \\
\hline PL 11 łódzkie & 0.057 & 0.105 & 0.54 & 0.01 & 1.06 & 0.06 \\
\hline PL 52 opolskie & -0.092 & 0.108 & -0.85 & -0.02 & 0.91 & -0.09 \\
\hline PL 63 pomorskie & -0.098 & 0.101 & -0.98 & -0.02 & 0.91 & -0.09 \\
\hline PL 22 śląskie & -0.001 & 0.103 & -0.01 & -0.0003 & 0.99 & -0.0006 \\
\hline PL43 lubuskie & -0.004 & 0.108 & -0.03 & -0.001 & 0.99 & -0.004 \\
\hline Rural area & 0.403 & 0.048 & 8.43 & 0.09 & 1.50 & 49.70 \\
\hline $\begin{array}{l}\text { City with less than } 2 \text { thousand } \\
\text { inhabitants }\end{array}$ & 0.471 & 0.354 & 1.33 & 0.11 & 1.60 & 0.60 \\
\hline $\begin{array}{l}\text { City with more than } 2 \text { thousand } \\
\text { and less than } 5 \text { thousand } \\
\text { inhabitants }\end{array}$ & 0.271 & 0.102 & 2.67 & 0.06 & 1.31 & 31.15 \\
\hline $\begin{array}{l}\text { City with more than } 5 \text { thousand } \\
\text { and less than } 10 \text { thousand } \\
\text { inhabitants }\end{array}$ & 0.383 & 0.093 & 4.10 & 0.09 & 1.47 & 46.61 \\
\hline $\begin{array}{l}\text { City with more than } 10 \text { thousand } \\
\text { and less than } 20 \text { thousand } \\
\text { inhabitants }\end{array}$ & 0.280 & 0.068 & 4.12 & 0.07 & 1.32 & 32.26 \\
\hline $\begin{array}{l}\text { City with more } 20 \text { thousand } \\
\text { and less than } 50 \text { thousand } \\
\text { inhabitants }\end{array}$ & 0.297 & 0.062 & 4.83 & 0.07 & 1.35 & 34.56 \\
\hline $\begin{array}{l}\text { City with more than } 50 \text { thousand } \\
\text { and less than } 100 \text { thousand } \\
\text { inhabitants }\end{array}$ & 0.260 & 0.064 & 4.05 & 0.06 & 1.30 & 29.67 \\
\hline Company with 11-19 employees & -0.123 & 0.052 & -2.37 & -0.03 & 0.88 & -11.58 \\
\hline Company with 20-49 employees & -0.299 & 0.052 & -5.80 & -0.07 & 0.74 & -25.86 \\
\hline
\end{tabular}


Table 1. continued

\begin{tabular}{|c|c|c|c|c|c|c|}
\hline Explanatory Variables & $\begin{array}{l}\text { Coef- } \\
\text { ficient }\end{array}$ & $\begin{array}{l}\text { Std. } \\
\text { error }\end{array}$ & $Z$ & Slope & $\begin{array}{l}\text { Odds } \\
\text { ratio }\end{array}$ & $\begin{array}{c}\Delta \text { low } \\
\text { wage } \\
\text { risk }(\%)\end{array}$ \\
\hline $\begin{array}{l}\text { Company with 50-100 } \\
\text { employees }\end{array}$ & -0.357 & 0.056 & -6.36 & -0.08 & 0.70 & -30.01 \\
\hline $\begin{array}{l}\text { Company with 101-250 } \\
\text { employees }\end{array}$ & -0.535 & 0.061 & -8.81 & -0.11 & 0.59 & -41.44 \\
\hline $\begin{array}{l}\text { Company with more than } \\
251 \text { employees }\end{array}$ & -0.953 & 0.056 & -16.94 & -0.19 & 0.39 & -61.45 \\
\hline Private employer/sector & -0.187 & 0.048 & -3.86 & -0.04 & 0.83 & -17.02 \\
\hline Agriculture, forestry and fishing & 0.385 & 0.172 & 2.24 & 0.09 & 1.47 & 46.92 \\
\hline Mining and quarrying & 1.069 & 0.125 & 8.52 & 0.26 & 2.91 & 191.14 \\
\hline Manufacturing & 0.813 & 0.116 & 7.00 & 0.19 & 2.25 & 125.49 \\
\hline $\begin{array}{l}\text { Water supply, sewerage, waste } \\
\text { management and remediation } \\
\text { activities }\end{array}$ & 0.521 & 0.140 & 3.73 & 0.13 & 1.68 & 68.34 \\
\hline Construction & 0.646 & 0.165 & 3.92 & 0.16 & 1.91 & 90.80 \\
\hline Wholesale trade & -0.17 & 0.776 & -0.22 & -0.04 & 0.84 & -0.16 \\
\hline Transportation and storage & 0.552 & 0.206 & 2.68 & 0.13 & 1.74 & 73.59 \\
\hline $\begin{array}{l}\text { Accommodation and food } \\
\text { service activities }\end{array}$ & 0.821 & 0.205 & 4.01 & 0.20 & 2.27 & 127.17 \\
\hline Information and communication & 0.069 & 0.78 & 0.09 & 0.02 & 1.07 & 0.07 \\
\hline $\begin{array}{l}\text { Financial and insurance } \\
\text { activities }\end{array}$ & 0.649 & 0.280 & 2.32 & 0.16 & 1.91 & 91.41 \\
\hline Real estate activities & 1.583 & 0.573 & 2.76 & 0.37 & 4.87 & 386.74 \\
\hline $\begin{array}{l}\text { Professional, scientific and } \\
\text { technical activities }\end{array}$ & 1.587 & 0.274 & 5.79 & 0.37 & 4.89 & 388.76 \\
\hline $\begin{array}{l}\text { Administrative and support } \\
\text { service activities }\end{array}$ & 0.893 & 0.281 & 3.17 & 0.22 & 2.44 & 144.28 \\
\hline Education & 1.976 & 0.171 & 11.53 & 0.45 & 7.22 & 621.53 \\
\hline $\begin{array}{l}\text { Human health and social work } \\
\text { activities }\end{array}$ & 1.134 & 0.132 & 8.62 & 0.27 & 3.11 & 210.70 \\
\hline $\begin{array}{l}\text { Arts, entertainment and } \\
\text { recreation }\end{array}$ & 1.215 & 0.556 & 2.19 & 0.29 & 3.37 & 236.91 \\
\hline Other service activities & 1.173 & 0.208 & 5.65 & 0.28 & 3.23 & 223.11 \\
\hline $\begin{array}{l}\text { Activities of households as } \\
\text { employers }\end{array}$ & 0.738 & 0.199 & 3.70 & 0.18 & 2.09 & 109.18 \\
\hline $\begin{array}{l}\text { Activities of extraterritorial } \\
\text { organisations and bodies }\end{array}$ & 0.909 & 0.113 & 8.08 & 0.21 & 2.48 & 148.27 \\
\hline $\begin{array}{l}\text { Legislators, senior officials and } \\
\text { managers }\end{array}$ & -2.658 & 0.134 & -19.90 & -0.34 & 0.07 & -92.99 \\
\hline Professionals & -2.260 & 0.085 & -26.50 & -0.37 & 0.10 & -89.56 \\
\hline $\begin{array}{l}\text { Technicians and associate } \\
\text { professionals }\end{array}$ & -1.419 & 0.067 & -21.04 & -0.26 & 0.24 & -75.79 \\
\hline Clerks & -0.698 & 0.069 & -10.14 & -0.14 & 0.50 & -50.26 \\
\hline
\end{tabular}


Table 1. continued

\begin{tabular}{l|c|c|c|c|c|c}
\hline Explanatory Variables & $\begin{array}{c}\text { Coef- } \\
\text { ficient }\end{array}$ & $\begin{array}{c}\text { Std. } \\
\text { error }\end{array}$ & $Z$ & Slope & $\begin{array}{c}\text { Odds } \\
\text { ratio }\end{array}$ & $\begin{array}{c}\Delta \text { low } \\
\text { wage } \\
\text { risk (\%) }\end{array}$ \\
\hline $\begin{array}{l}\text { Skilled agricultural and fishery } \\
\text { workers }\end{array}$ & -0.14 & 0.204 & -0.69 & -0.03 & 0.87 & -0.13 \\
\hline Craft and related trades workers & -0.416 & 0.063 & -6.55 & -0.09 & 0.66 & -34.02 \\
\hline $\begin{array}{l}\text { Plant and machine operators } \\
\text { and assemblers }\end{array}$ & -0.552 & 0.065 & -8.48 & -0.12 & 0.58 & -42.44 \\
\hline Elementary occupations & 0.613 & 0.069 & 8.92 & 0.15 & 1.85 & 84.67 \\
\hline No occupation & -1.231 & 0.637 & -1.93 & -0.21 & 0.29 & -70.79 \\
\hline Mobile worker & -0.676 & 0.083 & -8.13 & -0.14 & 0.51 & -49.14 \\
\hline $\begin{array}{l}\text { Work commuting distance }- \\
\text { longer than 50 km }\end{array}$ & -1.226 & 0.101 & -12.12 & -0.22 & 0.29 & -70.65 \\
\hline $\begin{array}{l}\text { Work commuting distance }- \\
\text { longer than 21 km and shorter } \\
\text { than 50 km }\end{array}$ & -0.577 & 0.060 & -9.66 & -0.12 & 0.56 & -43.83 \\
\hline $\begin{array}{l}\text { Work commuting distance }- \\
\text { longer than 6 km and shorter } \\
\text { than 20 km }\end{array}$ & -0.173 & 0.038 & -4.53 & -0.04 & 0.84 & -15.91 \\
\hline Work-at-home & 0.059 & 0.28 & 0.21 & 0.01 & 1.06 & 0.06 \\
\hline Full-time employment & -2.306 & 0.097 & -23.80 & -0.51 & 0.10 & -90.03 \\
\hline $\begin{array}{l}\text { Willingness to work longer in } \\
\text { return for higher pay }\end{array}$ & 0.398 & 0.055 & 7.26 & 0.09 & 1.49 & 48.90 \\
\hline Search for another job & 0.494 & 0.118 & 4.19 & 0.12 & 1.64 & 63.83 \\
\hline ISCED field of Education 100 & -0.123 & 0.098 & -1.26 & -0.03 & 0.88 & -0.12 \\
\hline ISCED field of Education 440 & 0.364 & 0.177 & 2.05 & 0.09 & 1.44 & 43.90 \\
\hline ISCED field of Education 460 & -0.026 & 0.444 & -0.06 & -0.01 & 0.97 & -0.03 \\
\hline ISCED field of Education 481 & 0.310 & 0.145 & 2.13 & 0.07 & 1.36 & 36.35 \\
\hline ISCED field of Education 482 & -0.733 & 1.358 & -0.54 & -0.15 & 0.48 & -0.52 \\
\hline ISCED field of Education 500 & 0.00 & 0.062 & 0.00 & 0.00 & 1.00 & 0.00 \\
\hline ISCED field of Education 600 & 0.134 & 0.076 & 1.78 & 0.03 & 1.14 & 14.38 \\
\hline ISCED field of Education 700 & 0.302 & 0.091 & 3.32 & 0.07 & 1.35 & 35.20 \\
\hline ISCED field of Education 800 & -0.068 & 0.08 & -0.85 & -0.01 & 0.93 & -0.07 \\
\hline ISCED field of Education 900 & 0.134 & 0.624 & 0.21 & 0.03 & 1.14 & 0.14 \\
\hline ISCED field of Education 000 & 0.859 & 0.078 & 11.04 & 0.21 & 2.36 & 136.01 \\
\hline Nots St & & & & & & \\
\hline
\end{tabular}

Notes: Statistically significant parameters (for $\alpha \leq 0.1$ ) were bolded. Number of cases correctly classified: $79.4 \%$, sensitivity: $69 \%$, specificity: $86 \%$, Odds ratio: 14 , McFadden $R$-squared: 0.35 , Adjusted $R$-sq: 0.34 , Likelihood ratio test: Chi-square $(87)=12569.3$ [p-value $0.00<0.1$ ],$N=26933$. NUTS 2013 codes, ISCED fields of education 2011 codes, *high school certificate.

Source: Own calculation on LFS data. 
Table 2. Parameter estimates of being low-wage earner ( $2 / 3$ of the national median), sample restricted to full-time employees, Poland, 2014

\begin{tabular}{|c|c|c|c|c|c|c|}
\hline Explanatory Variables & $\begin{array}{l}\text { Coef- } \\
\text { ficient }\end{array}$ & $\begin{array}{l}\text { Std. } \\
\text { error }\end{array}$ & $Z$ & Slope & $\begin{array}{l}\text { Odds } \\
\text { ratio }\end{array}$ & $\begin{array}{c}\Delta \text { low } \\
\text { wage } \\
\text { risk (\%) }\end{array}$ \\
\hline Constant & 0.983 & 0.112 & 8.80 & & 2.67 & \\
\hline Male & -1.317 & 0.045 & -29.04 & -0.28 & 0.27 & -73.20 \\
\hline Single & 0.214 & 0.053 & 4.07 & 0.05 & 1.24 & 23.88 \\
\hline Widowed & 0.16 & 0.122 & 1.31 & 0.03 & 1.17 & -0.17 \\
\hline Divorced & 0.133 & 0.084 & 1.6 & 0.02 & 1.14 & -0.14 \\
\hline Age 15-24 & -0.281 & 0.105 & -2.67 & -0.06 & 0.76 & -24.46 \\
\hline Age 25-30 & -0.148 & 0.071 & -2.07 & -0.03 & 0.86 & -13.73 \\
\hline Age 50-59 & 0.398 & 0.067 & 5.93 & 0.09 & 1.49 & 48.81 \\
\hline Age 60-69 & 0.674 & 0.126 & 5.35 & 0.16 & 1.96 & 96.12 \\
\hline Age 70 plus & 2.241 & 1.030 & 2.18 & 0.50 & 9.41 & 840.51 \\
\hline Retirement & 0.95 & 0.21 & 4.54 & 0.23 & 2.59 & 159.3 \\
\hline Disability pension & 1.13 & 0.30 & 3.80 & 0.27 & 2.59 & 211.0 \\
\hline Being a kept person & 0.49 & 0.43 & 1.14 & 0.11 & 1.63 & 0.63 \\
\hline Having a farm & 0.22 & 0.09 & 2.67 & 0.05 & 1.26 & 0.26 \\
\hline Family responsibilities & 0.645 & 0.237 & 2.72 & 0.15 & 1.91 & 90.69 \\
\hline Disabled & 0.417 & 0.639 & 0.65 & 0.08 & 1.52 & 0.52 \\
\hline Ph.D. degree and higher & -1.157 & 0.596 & -1.94 & -0.19 & 0.31 & -68.54 \\
\hline Master degree & -0.862 & 0.076 & -11.35 & -0.16 & 0.42 & -57.77 \\
\hline Bachelor & -0.290 & 0.088 & -3.31 & -0.06 & 0.75 & -25.21 \\
\hline $\begin{array}{l}\text { Vocational education, no } \\
\text { examination }\end{array}$ & 0.298 & 0.091 & 3.29 & 0.07 & 1.35 & 34.72 \\
\hline Secondary school* & -0.743 & 0.102 & -7.32 & -0.14 & 0.48 & -52.43 \\
\hline $\begin{array}{l}\text { Secondary school, no } \\
\text { examination }\end{array}$ & -0.523 & 0.146 & -3.59 & -0.10 & 0.59 & -40.72 \\
\hline Basic vocational education & 0.539 & 0.053 & 10.19 & 0.12 & 1.71 & 71.38 \\
\hline Gymnasium & -0.522 & 0.216 & -2.42 & -0.10 & 0.59 & -40.70 \\
\hline Primary & -1.422 & 1.673 & -0.85 & -0.22 & 0.24 & -0.76 \\
\hline College (kolegium) & 0.118 & 0.856 & 0.14 & 0.01 & 1.12 & 0.12 \\
\hline Post-secondary school & 0.031 & 0.105 & 0.29 & 0.01 & 1.03 & 0.03 \\
\hline No overall job tenure & 1.873 & 0.172 & 10.90 & 0.44 & 6.51 & 551.05 \\
\hline $\begin{array}{l}\text { Overall job tenure less than } \\
1 \text { year }\end{array}$ & 1.551 & 0.133 & 11.66 & 0.37 & 4.72 & 371.64 \\
\hline $\begin{array}{l}\text { Overall job tenure more than } \\
1 \text { year and less than } 5 \text { years } \\
\end{array}$ & 0.595 & 0.077 & 7.70 & 0.14 & 1.81 & 81.37 \\
\hline $\begin{array}{l}\text { Overall job tenure more than } \\
10 \text { years and less than } 20 \text { years }\end{array}$ & -0.455 & 0.065 & -7.00 & -0.09 & 0.63 & -36.58 \\
\hline $\begin{array}{l}\text { Overall job tenure more than } \\
20 \text { years and less than } 30 \text { years }\end{array}$ & -0.657 & 0.072 & -9.15 & -0.13 & 0.52 & -48.18 \\
\hline $\begin{array}{l}\text { Overall job tenure more than } \\
30 \text { years and less than } 40 \text { years }\end{array}$ & -1.108 & 0.094 & -11.82 & -0.20 & 0.33 & -66.97 \\
\hline
\end{tabular}


Table 2. continued

\begin{tabular}{|c|c|c|c|c|c|c|}
\hline Explanatory Variables & $\begin{array}{l}\text { Coef- } \\
\text { ficient }\end{array}$ & $\begin{array}{l}\text { Std. } \\
\text { error }\end{array}$ & $Z$ & Slope & $\begin{array}{l}\text { Odds } \\
\text { ratio }\end{array}$ & $\begin{array}{c}\Delta \text { low } \\
\text { wage } \\
\text { risk }(\%)\end{array}$ \\
\hline $\begin{array}{l}\text { Overall job tenure more than } \\
40 \text { years }\end{array}$ & -1.064 & 0.146 & -7.29 & -0.18 & 0.34 & -65.51 \\
\hline PL 51 dolnośląskie & -0.244 & 0.090 & -2.70 & -0.05 & 0.78 & -21.67 \\
\hline PL 61 kujawsko-pomorskie & 0.457 & 0.085 & 5.36 & 0.10 & 1.58 & 57.96 \\
\hline PL 31 lubelskie & 0.447 & 0.075 & 5.99 & 0.10 & 1.56 & 56.38 \\
\hline PL 11 lódzkie & 0.147 & 0.086 & 1.70 & 0.03 & 1.16 & 15.79 \\
\hline PL 21 małopolskie & -0.235 & 0.085 & -2.76 & -0.05 & 0.79 & -20.96 \\
\hline PL12 mazowieckie & -0.324 & 0.072 & -4.53 & -0.07 & 0.72 & -27.68 \\
\hline PL 52 opolskie & -0.184 & 0.089 & -2.06 & -0.04 & 0.83 & -16.79 \\
\hline PL 32 podkarpackie & 0.722 & 0.084 & 8.58 & 0.17 & 2.06 & 105.80 \\
\hline PL 34 podlaskie & 0.394 & 0.077 & 5.09 & 0.09 & 1.48 & 48.24 \\
\hline PL 33 świętokrzyskie & 0.422 & 0.081 & 5.18 & 0.10 & 1.52 & 52.44 \\
\hline PL 62 warmińsko-mazurskie & 0.215 & 0.079 & 2.72 & 0.05 & 1.24 & 24.05 \\
\hline PL 41 wielkopolskie & 0.213 & 0.080 & 2.66 & 0.05 & 1.24 & 23.70 \\
\hline PL 63 pomorskie & -0.042 & 0.113 & -0.38 & -0.02 & 0.96 & -0.04 \\
\hline PL 22 śląskie & 0.039 & 0.114 & 0.35 & 0.002 & 1.04 & 0.04 \\
\hline PL43 lubuskie & 0.042 & 0.12 & 0.35 & 0.01 & 1.04 & 0.04 \\
\hline Rural area & 0.404 & 0.053 & 7.69 & 0.09 & 1.50 & 49.77 \\
\hline $\begin{array}{l}\text { City with less than } 2 \text { thousand } \\
\text { inhabitants }\end{array}$ & 0.443 & 0.426 & 1.04 & 0.09 & 1.56 & 0.56 \\
\hline $\begin{array}{l}\text { City with more than } 2 \text { thousand } \\
\text { and less than } 5 \text { thousand } \\
\text { inhabitants }\end{array}$ & 0.257 & 0.109 & 2.35 & 0.06 & 1.29 & 29.35 \\
\hline $\begin{array}{l}\text { City with more than } 5 \text { thousand } \\
\text { and less than } 10 \text { thousand } \\
\text { inhabitants }\end{array}$ & 0.340 & 0.105 & 3.23 & 0.08 & 1.41 & 40.54 \\
\hline $\begin{array}{l}\text { City with more than } 10 \\
\text { thousand and less than } 20 \\
\text { thousand inhabitants }\end{array}$ & 0.291 & 0.076 & 3.83 & 0.06 & 1.34 & 33.76 \\
\hline $\begin{array}{l}\text { City with more } 20 \text { thousand } \\
\text { and less than } 50 \text { thousand } \\
\text { inhabitants }\end{array}$ & 0.350 & 0.069 & 5.05 & 0.08 & 1.42 & 41.90 \\
\hline $\begin{array}{l}\text { City with more than } 50 \\
\text { thousand and less than } 100 \\
\text { thousand inhabitants }\end{array}$ & 0.328 & 0.071 & 4.61 & 0.07 & 1.39 & 38.76 \\
\hline Company with 11-19 employees & -0.199 & 0.058 & -3.40 & -0.04 & 0.82 & -18.01 \\
\hline Company with 20-49 employees & -0.309 & 0.057 & -5.38 & -0.06 & 0.73 & -26.60 \\
\hline $\begin{array}{l}\text { Company with 50-100 } \\
\text { employees }\end{array}$ & -0.413 & 0.062 & -6.65 & -0.08 & 0.66 & -33.82 \\
\hline $\begin{array}{l}\text { Company with 101-250 } \\
\text { employees }\end{array}$ & -0.576 & 0.066 & -8.70 & -0.11 & 0.56 & -43.78 \\
\hline
\end{tabular}


Table 2. continued

\begin{tabular}{|c|c|c|c|c|c|c|}
\hline Explanatory Variables & $\begin{array}{l}\text { Coef- } \\
\text { ficient }\end{array}$ & $\begin{array}{l}\text { Std. } \\
\text { error }\end{array}$ & $Z$ & Slope & $\begin{array}{l}\text { Odds } \\
\text { ratio }\end{array}$ & $\begin{array}{c}\Delta \text { low } \\
\text { wage } \\
\text { risk }(\%)\end{array}$ \\
\hline $\begin{array}{l}\text { Company with more than } \\
\text { 251employees }\end{array}$ & -1.052 & 0.062 & -17.04 & -0.19 & 0.35 & -65.06 \\
\hline Agriculture, forestry and fishing & -0.092 & 0.801 & -0.12 & -0.001 & 0.91 & -0.09 \\
\hline Mining and quarrying & 0.416 & 0.089 & 4.69 & 0.09 & 1.52 & 51.54 \\
\hline Manufacturing & 0.196 & 0.072 & 2.72 & 0.04 & 1.22 & 21.67 \\
\hline $\begin{array}{l}\text { Water supply, sewerage, waste } \\
\text { management and remediation } \\
\text { activities }\end{array}$ & -0.055 & 0.789 & -0.07 & 0.02 & 0.95 & -0.05 \\
\hline Construction & 0.086 & 0.794 & 0.11 & 0.04 & 1.09 & 0.09 \\
\hline $\begin{array}{l}\text { Wholesale, retail trade, repair of } \\
\text { motor vehicles and motorcycles }\end{array}$ & -0.739 & 0.169 & -4.38 & -0.13 & 0.48 & -52.25 \\
\hline Transportation and storage & -0.059 & 0.807 & -0.07 & 0.01 & 0.94 & -0.06 \\
\hline $\begin{array}{l}\text { Accommodation and food service } \\
\text { activities }\end{array}$ & 0.343 & 0.805 & 0.43 & 0.10 & 1.41 & 0.41 \\
\hline $\begin{array}{l}\text { Information and } \\
\text { communication }\end{array}$ & -0.592 & 0.199 & -2.97 & -0.11 & 0.55 & -44.66 \\
\hline Financial and insurance activities & 0.147 & 0.831 & 0.18 & & 1.16 & 0.16 \\
\hline Real estate activities & 1.096 & 0.624 & 1.76 & 0.26 & 2.99 & 199.22 \\
\hline $\begin{array}{l}\text { Professional, scientific and } \\
\text { technical activities }\end{array}$ & 0.872 & 0.292 & 2.99 & 0.21 & 2.39 & 139.21 \\
\hline $\begin{array}{l}\text { Administrative and support } \\
\text { service activities }\end{array}$ & 0.171 & 0.834 & 0.21 & 0.05 & 1.19 & 0.19 \\
\hline Education & 1.580 & 0.159 & 9.91 & 0.38 & 4.85 & 385.28 \\
\hline $\begin{array}{l}\text { Human health and social work } \\
\text { activities }\end{array}$ & 0.464 & 0.100 & 4.63 & 0.11 & 1.59 & 59.08 \\
\hline Arts, entertainment and recreation & 0.608 & 0.983 & 0.62 & 0.19 & 1.84 & 0.84 \\
\hline Other service activities & 0.436 & 0.205 & 2.12 & 0.10 & 1.55 & 54.67 \\
\hline $\begin{array}{l}\text { Activities of households as } \\
\text { employers }\end{array}$ & 0.189 & 0.807 & 0.23 & 0.07 & 1.21 & 0.21 \\
\hline $\begin{array}{l}\text { Activities of extraterritorial } \\
\text { organisations and bodies }\end{array}$ & 0.230 & 0.065 & 3.54 & 0.05 & 1.26 & 25.88 \\
\hline $\begin{array}{l}\text { Legislators, senior officials and } \\
\text { managers }\end{array}$ & -2.678 & 0.148 & -18.10 & -0.30 & 0.07 & -93.13 \\
\hline Professionals & -2.289 & 0.097 & -23.67 & -0.33 & 0.10 & -89.87 \\
\hline $\begin{array}{l}\text { Technicians and associate } \\
\text { professionals }\end{array}$ & -1.452 & 0.073 & -19.96 & -0.24 & 0.23 & -76.58 \\
\hline Clerks & -0.755 & 0.075 & -10.13 & -0.14 & 0.47 & -53.01 \\
\hline $\begin{array}{l}\text { Skilled agricultural and fishery } \\
\text { workers }\end{array}$ & 0.039 & 0.243 & 0.16 & 0.02 & 1.04 & 0.04 \\
\hline $\begin{array}{l}\text { Craft and related trades } \\
\text { workers }\end{array}$ & -0.354 & 0.070 & -5.08 & -0.07 & 0.70 & -29.79 \\
\hline
\end{tabular}


Table 2. continued

\begin{tabular}{l|r|r|r|r|r|r}
\hline Explanatory Variables & $\begin{array}{c}\text { Coef- } \\
\text { ficient }\end{array}$ & $\begin{array}{c}\text { Std. } \\
\text { error }\end{array}$ & $Z$ & Slope & $\begin{array}{c}\text { Odds } \\
\text { ratio }\end{array}$ & $\begin{array}{c}\Delta \text { low } \\
\text { wage } \\
\text { risk (\%) }\end{array}$ \\
\hline $\begin{array}{l}\text { Plant and machine operators } \\
\text { and assemblers }\end{array}$ & -0.502 & 0.071 & -7.04 & -0.10 & 0.61 & -39.47 \\
\hline Elementary occupations & 0.685 & 0.076 & 9.00 & 0.16 & 1.98 & 98.34 \\
\hline Mobile worker & -0.616 & 0.098 & -6.31 & -0.12 & 0.54 & -46.00 \\
\hline $\begin{array}{l}\text { Work commuting distance - } \\
\text { longer than 50 km }\end{array}$ & -1.107 & 0.114 & -9.69 & -0.18 & 0.33 & -66.94 \\
\hline $\begin{array}{l}\text { Work commuting distance - } \\
\text { longer than 21 km and shorter } \\
\text { than 50 km }\end{array}$ & & & & & & \\
\hline $\begin{array}{l}\text { Work commuting distance - } \\
\text { longer than 6 km and shorter } \\
\text { than 20 km }\end{array}$ & -0.557 & 0.066 & -8.39 & -0.11 & 0.57 & -42.69 \\
\hline Work-at-home & -0.136 & 0.043 & -3.19 & -0.03 & 0.87 & -12.71 \\
\hline ISCED field of Education 100 & 0.069 & 0.115 & 0.6 & 0.01 & 1.07 & 0.07 \\
\hline ISCED field of Education 440 & 0.360 & 0.195 & 1.84 & 0.08 & 1.43 & 43.29 \\
\hline ISCED field of Education 460 & 0.116 & 0.519 & 0.22 & 0.02 & 1.12 & 0.12 \\
\hline ISCED field of Education 481 & 0.267 & 0.157 & 1.70 & 0.06 & 1.31 & 30.55 \\
\hline ISCED field of Education 482 & 0.639 & 1.154 & 0.55 & 0.11 & 1.89 & 0.89 \\
\hline ISCED field of Education 500 & -0.026 & 0.068 & -0.38 & -0.01 & 0.97 & -0.03 \\
\hline ISCED field of Education 600 & 0.069 & 0.094 & 0.73 & 0.01 & 1.07 & 0.07 \\
\hline ISCED field of Education 700 & 0.274 & 0.105 & 2.62 & 0.06 & 1.32 & 31.53 \\
\hline ISCED field of Education 800 & -0.063 & 0.088 & -0.71 & -0.01 & 0.94 & -0.06 \\
\hline ISCED field of Education 900 & -0.793 & 0.745 & -1.07 & -0.13 & 0.45 & -0.55 \\
\hline ISCED field of Education 000 & 0.840 & 0.086 & 9.76 & 0.19 & 2.32 & 131.52 \\
\hline
\end{tabular}

Notes: Statistically significant parameters (for $\alpha \leq 0.1$ ) were bolded. Number of cases correctly classified: $78.5 \%$, sensitivity: $70 \%$, specificity: $83 \%$, Odds ratio: 11 , McFadden $R$-squared: 0.31 , Adjusted $R$-sq: 0.30 , Likelihood ratio test: Chi-square $(71)=8547.25$ [p-value $0.00<0.1$ ],$N=20816$. NUTS 2013 codes, ISCED fields of education 2011 codes, *high school certificate.

Source: Own calculation on LFS data. 